\title{
PSYCHOLOGICAL ATTRIBUTES OF SUCCESSFUL TRAINEE ACCOUNTANTS
}

\author{
ESMARI ŠTRBAC \\ GERT ROODT \\ Department of Human Resource Management \\ University of Johannesburg
}

\begin{abstract}
It is suggested that certain psychological attributes of accounting graduates are significant predictors of the later success of trainee accountants in the work environment. Since selection is a key human resources function in public accounting firms the present study investigated the relationship between academic performance, specific personality traits, examination pass rate and the work performance of a sample $(\mathrm{N}=77)$ of trainee accountants from an international, mid-sized firm. The results indicate that the majority of cases could be correctly predicted as successful or not by a verbal ability variable and that the criterion measure developed for this study (Cronbach alpha $=0,95$ ) can be used successfully to measure the work performance of trainee accountants. The importance of academic performance as well as the pass rate in the qualifying examinations are also discussed.
\end{abstract}

\section{OPSOMMING}

Daar word gesuggereer dat sekere sielkundige eienskappe van rekeningkunde gegradueerdes as voorspellers van hul latere sukses in die werkomgewing kan dien. Aangesien keuring 'n kernfunksie van die menslikehulpbronaktiwiteite binne openbare ouditeursfirmas is, het hierdie studie die verhouding tussen akademiese prestasie, spesifieke persoonlikheidstrekke, die eksamenslaagsyfer en die werkprestasie van 'n steekproef $(\mathrm{N}=77)$ kwekelinggeoktrooieerde-rekenmeesters binne 'n internasionale, gemiddelde grootte firma ondersoek. Die resultate dui daarop dat die meerderheid gevalle korrek as suksesvol aldan nie voorspel kan word deur 'n verbale vermoë-veranderlike en dat die kriteriuminstrument wat vir hierdie studie ontwikkel is (Cronbach alfa $=0,95$ ), gebruik kan word om die werkprestasie van hierdie kwekelinge te meet. Die belangrikheid van akademiese prestasie en die slaagsyfer in die kwalifiserende eksamens word ook bespreek.

One of the most pervasive concerns of public accounting firms is attracting and retaining successful trainee chartered accountants (trainees). The competition for these sought-after graduates is especially strong between the "Big 8" accounting firms, both nationally and internationally. Public accounting is a people business and the firm's most valuable asset is its human resources (Boress, 1999). The success of a firm begins with having the right employees who possess suitable attributes and skills (Holub, 1998). Karys (1998) emphasised that accounting firms regard selecting and attracting the best graduates of utmost importance and employers are offering various innovative arrangements to attract the best.

The objective of this study was to determine whether certain psychological attributes (traits and behaviours) of accounting graduates can predict their job performance within the accountancy profession. Furthermore, the study will determine the psychological profiles of these graduates with the aim of indicating the differences in profiles of those who are regarded as successful, and those who are not. The findings may then be used to give accounting firms an advantage in recruiting a higher percentage of successful accounting graduates in South Africa, since the selection of these graduates has important implications for the productivity and effectiveness of the accounting firm, and the investment of money into training these graduates into Chartered Accountants is recommended for each firm (Chatman, 1991).

\section{Defining trainee accountants}

Public accounting firms recruit graduates into the accounting discipline as trainees. The South African Institute for Chartered Accountants (SAICA) stipulates that traineeship (training period at the firm) consists of three years for a trainee possessing a degree in accountancy (SAICA Training Manual, 2004). Trainees have to write two parts of a Qualifying Exam (QE) as stipulated by The Public Accountants' and Auditors' Board of South Africa (PAAB) after they have obtained an Honours degree or equivalent. Trainees cannot register as Chartered Accountants (CA) on completion of their traineeship unless they have passed both these examinations (PAAB, 1998).

Requests for copies should be addressed to: G Roodt, Department of Human Resource Management, University of Johannesburg, PO Box 524, Auckland Park, 2006
Since auditing and accounting are the core services of public accounting firms, they require trainees who are successful in their professional examinations, and perform accordingly on the job (Harvey-Cook, 2000). SAICA has established that the experience during traineeship has to be such that four skills are being developed namely, intellectual skills, interpersonal skills, communication skills and a sense of responsibility (SAICA Training Manual, 2004). The level of responsibility entrusted to trainees and the value of those trainees to employers is dependent on trainees obtaining the necessary academic qualifications and achievement in the QE (Harvey-Cook, 2000). However, achievement in the QE is only one of the success factors that should be evaluated in the assessment of trainees.

\section{Success factors in training trainee accountants}

In a study conducted by Hulme (1998) no significant difference was identified between success indicators of trainees from different accounting firms in South Africa, the United States of America, Australia and England. Gaffney, McEwen and Welsch (1990) indicated that few differences exist in perceptions between males and females about the importance of various success factors that could lead to professional success. This has caused researchers to investigate other traits, skills and abilities. Collins (1987) suggested that studying personality preferences of the various firms could help recruiters predict what personality types are drawn to the accounting profession. Caldwell, Chatman and O'Reilly (1990) stated that variables such as personal and job characteristics could be linked to organisational commitment and performance.

\section{Personality traits}

Anastasi (1997) referred to personality as intellectual as well as affective traits of a person. Holland (1973) viewed a personality type as "the product of a characteristic interaction between a variety of cultural and personal forces, including peers, parents, social class, culture and the physical environment". Holland (1973) proposed that the tendency of individuals to be successful in a given environment is a function of the extent of congruence between their personality type and the type of environment. Furthermore, he indicated that the closer a person resembles the personality profile that has been established for that occupation, the greater is the expected vocational aspiration and eventual achievement in the field. 
Day and Silverman (1989) indicated in their study of qualified accountants that personality variables, with cognitive ability taken into account, are significantly related to aspects of job performance. Cummings, Bennet and Normand (2001) emphasised that accountancy graduates have to begin developing their problem solving skills, oral and written communication skills, computer skills and interpersonal skills during their undergraduate studies. Jeffords, Scheidt and Thibadoux (2000) stated that it is important that recruiters soon match the personality of the graduate to the business environment.

Simon and Kedslie (1997) concluded that recruiters of accountancy firms looked for personality traits such as interpersonal sensitivity/skills, integrity, self-confidence, flexibility, leadership potential, innovation, the ability to apply critical reasoning and adaptability. Rynes and Gerhart (1990) indicated that more research should be done on aspects of personal characteristics that are most important in determining what will make an applicant successful in that specific firm.

\section{Interpersonal skills/abilities}

Collins (1987) indicated that accounting firms look for more mature, entrepreneurial graduates who behave in a mature, professional manner. Kirsch and Leathers (1993) identified that professionalism leads to trainee performance, and that successful interpersonal skills/abilities exhibited by employees in the work environment, including integrity, promote the building of professional working relationships. Jeffords et al. (2000) indicated that in addition to strong interpersonal skills, organisational or professional knowledge, technical competence and intellectual ability are also strong indicators of success.

Chatman (1991) concluded that exhibiting traits such as openness to the influence of the socialisation processes of the organisation, could lead to trainees having a more satisfying work experience during their first year of traineeship than those who are not open to socialisation. Grey (1998) confirmed that professional success tends to be defined in terms of appropriate forms of behaviour (social and professional) as well as technical skills.

\section{Intellectual ability and academic achievement}

Herriot (1984) warned that organisations should not only concentrate on the personality characteristics of the graduate they recruit, but also on the intellectual and technical abilities of that graduate. Todd (1991) indicated that the value of using intellectual ability alone as a predictor seems to be decreasing and it should be viewed in conjunction with another predictor such as academic achievement. Factors such as perseverance, determination, dedication, persistence and willingness contribute to good academic achievement (Todd, 1991).

The study conducted by Harvey-Cook and Taffler (1997) supported the notion that the academic performance of accounting students including their verbal ability should be considered during selection and recruitment. Van der Walt and Esterhuyse (1987) postulated that variables such as good results in school subjects of first language, accounting and mathematics are significant in predicting academic achievement of graduates.

Harvey-Cook (2000) emphasised that examination failure is the major cause of trainees cancelling their traineeship contract with firms, at a great cost to the employer. Dunn and Hall (1984), who researched the relationship between certain QE candidate attributes and the candidate's performance, supported this. Dunn and Hall (1984) concluded that a positive correlation existed between candidates' accounting grades averages and their QE results.

Nell, Kamfer and Van der Merwe (1996) concluded that all intelligent people are not necessarily successful in their careers, since personality traits and motivation contribute to the way in which people apply their skills and knowledge, and that the development of a person's competence is determined by motivational and personality structures, attitudes, needs and interests. Rather than stereotyping graduates, the values, traits and technical abilities of trainees, and those which firms impose on them, should be investigated to establish a good fit for performance (Anderson-Gough et al., 1998).

\section{Technical ability}

Holland (1973) proposed that technical competence could not be viewed as being separate or independent from personality, since it is the implementation of a person's self-concept. Day and Silverman (1989) emphasised that, in conjunction with psychological traits that are relevant to the profession, individual cognitive ability and technical skills contribute to the success of a trainee. Should a poor match be made between the cognitive and technical abilities of a graduate and the job requirements, poor job performance and costly turnover could result (Kirsch \& Leathers, 1993). Kirsch and Leathers (1993) found that conceptual understanding of accounting and auditing and the execution of that understanding of numerical information, play a role in whether trainees are regarded as successful or not in their work environment. In an earlier study Chatman (1988) found a significant relation between the person-job fit of trainees and their measured performance.

Seeker and Wilson (1998) maintained that when evaluating an individual's performance, one needs to ensure that the performance statements made are objective and can be measured quantitatively. The importance of considering the performance assessments during the performance evaluation of a trainee is supported by Anderson-Gough, Grey and Robson (1998) who stated that formal performance appraisal systems should be used as a major tool in shaping the behaviour of trainees in the firm. The competencies being rated should reflect the firm's view of the behaviour that must be displayed and the type of person that the firm accepts. Anderson-Gough et al. (1998) also warned that there is a limit to which the performance appraisal process can structure progression within the firm. Herriot (1984) emphasised that ratings by others can be regarded as important evidence if the raters are reminded to take the behavioural and situational context into account and if the standards of comparison, according to which they will operate, are made clear.

Hulme (1998) argued that traits that might make trainees successful during their traineeship include academic ability, numerical ability, analytical ability, interpersonal ability, integrity, adaptability, knowledge of the profession, and communication, and that it is not sufficient to have only technical skills.

\section{Selection and recruitment of trainees}

Barber (1998) stated that, given the costly implications of not recruiting the most suitable graduates, attention has to be focused on recruitment as an important aspect of determining how successful a graduate will be in the organisation. Caldwell and O'Reilly (1990) warned that limited conclusions could be drawn concerning the applicant when recruiters fail to describe the personality profile of the applicant. Recruiters should also identify and select applicants who demonstrate characteristics that are similar to those of successful trainees within the firm. Le Roux, Schepers and Lessing (1997) indicated that the individual characteristics of employees, such as interests, aptitude, abilities, career expectations and aspirations as well as career maturity could be regarded as a category that might ultimately influence labour turnover within the organisation.

Since public accounting firms have similar structures, jobs and career paths, recruitment should focus on the match between the psychological profile of the applicants and expectations of the position of a trainee (Chatman, 1991). Dean, Ferris and Konstans (1988) reported that the selection of graduates who would realistically fit into and commit to the organisation with regard to mutual expectations could also avoid mutual disappointment. Elkins and Phillips (2000) summarised that job post-hire behaviour could be improved through a selection process that includes jobrelated (the "extent to which a test appears to measure aspects of the job that are important for performance") tests and assessments. 


\section{Psychological testing}

Personality testing should be used to reduce staff turnover and increase human resource efficiency by finding, with greater accuracy, the best person for a particular position (England, 1991). Anastasi (1997) stated that a personality test refers to measures of various characteristics, including emotional states, interpersonal relations, motivations, interests and attitudes. Measurement of personality can be done through personality questionnaires as well as performance or situational tests. Jones (1991) maintained that psychological, and specifically personality testing, should be applied as a more objective tool than only relying on the interview in the selection process. However, Larkin (1990) claimed that recruiter firms should still consider the personal and academic characteristics of graduates and the way in which they behave in the interview, as important indicators of success.

Kristhof (1996) agreed that recruiters should use psychological tests and individual profiles to help them recognise applicant qualities that might establish a good fit within the organisation and lead to increased performance. Harvey-Cook and Taffler (1987) indicated that recruitment procedures should also include an assessment of graduates who show a clear interest and would want to stay in the profession in the long term. Although assessment centres are sometimes used for this purpose, this method would be too time-consuming and costly for the number of applicants who have to be screened where a shorter, effective psychological measurement might be just as productive.

Thomas and Thomas (1989) found that factors influencing trainees in their decisions to leave public accounting include the personality traits of these employees. Harvey-Cook and Taffler (1987) stated at the time that the accounting profession relies heavily on the interview for recruitment purposes, although extensive research literature relates to the inherent lack of validity thereof. Garavan and Morley (1997) concluded that inadequate recruitment tools and procedures lead to mutual feelings of disillusionment and frustration for both for employee and employer.

\section{Statement of the problem}

The previous section indicated various job-related traits and attributes of graduates that should be considered when making a selection decision. Boolsen and Theron (1996) indicated that although South African legislation is sensitive towards the use of psychological assessment during the selection process, it is accepted provided discrimination is ruled out.

In the light of the stated objective of the study and following the findings of previous studies, it is predicted that certain identified attributes of graduates may be linked to their success during traineeship. The most important personality traits that are expected to have a bearing on the trainees' successful training and practicing of their profession, were inferred from research findings and by performing a job analysis in respect of trainees. Against this background, the following research question was formulated:

Can the success of trainee accountants in traineeship (as reflected in their performance ratings) be predicted by their passing of the Qualifying Examination as first time writers, their average academic pass rate at university and their obtained scores on certain OPQ32n dimensions as well as on the Verbal Evaluation and Interpreting of Data Questionnaires? The selected OPQ dimensions were Data Rational, Evaluative, Adaptable, Details Conscious and Rule Following.

\section{RESEARCH DESIGN}

Research approach

In order to determine the relationship between the performance of trainees and the variables that impact upon their performance and since the differences between the various categories of trainees can be expressed numerically, a quantitative approach was followed. A field survey research design was followed and a sample of convenience drawn as the first author was employed at the firm.

As part of the retrospective (ex post facto) approach, documentary sources in the form of academic transcripts, results of a test battery and direct observation (performance evaluation scales) were statistically evaluated and reported on. Since previous research includes both descriptive and explanatory studies, this research serves the purpose of confirming that trainee performance correlates with specific psychological traits and academic performance. A multivariate, correlational data analysis approach was followed as the researcher was interested in the relationships between the personality, academic, verbal and numerical variables.

\section{Research methodology}

Participants

The biographic details of the participants in the study are presented in Table 1.

TABLE 1

DISTRIBUTION OF PARTRICIPANTS ACCORDING TO BIOGRAPHICAL/DEMOGRAPHICAL VARIABLES $(\mathbf{N}=\mathbf{7 7})$

\begin{tabular}{|c|c|c|}
\hline Variable & $\mathbf{N}$ & $(\%)$ \\
\hline \multicolumn{3}{|l|}{ Gender } \\
\hline Male & 39 & 50,1 \\
\hline Female & 38 & 49,9 \\
\hline Total & 77 & 100 \\
\hline \multicolumn{3}{|l|}{ Ethnicity } \\
\hline African & 9 & 11,7 \\
\hline Coloured & 1 & 1,3 \\
\hline Indian & 4 & 5,2 \\
\hline White & 61 & 79,2 \\
\hline Other & 2 & 2,6 \\
\hline Total & 77 & 100 \\
\hline \multicolumn{3}{|l|}{ Highest level of education } \\
\hline Grade 12 & 3 & 3,9 \\
\hline 3 Year graduate & 17 & 22,1 \\
\hline Post graduate & 57 & 74,0 \\
\hline Total & 77 & 100 \\
\hline \multicolumn{3}{|l|}{ University } \\
\hline Rand Afrikaans University & 21 & 27,3 \\
\hline University of the Witwatersrand & 20 & 26,0 \\
\hline University of South Africa & 21 & 27,3 \\
\hline University of Cape Town & 2 & 2,6 \\
\hline University of Pretoria & 13 & 16,8 \\
\hline Total & 77 & 100 \\
\hline \multicolumn{3}{|l|}{ Year of traineeship } \\
\hline First year & 23 & 29,8 \\
\hline Second year & 32 & 41,6 \\
\hline Third year & 22 & 28,6 \\
\hline Total & 77 & 100 \\
\hline \multicolumn{3}{|l|}{ Qualifying Examination Part 1} \\
\hline Passed first time & 39 & 50,6 \\
\hline Passed when repeated & 11 & 14,3 \\
\hline Did not write & 27 & 35,1 \\
\hline Total & 77 & 100 \\
\hline \multicolumn{3}{|l|}{ Qualifying Examination Part 2} \\
\hline Passed first time & 27 & 35,1 \\
\hline Passed when repeated & 5 & 6,5 \\
\hline Did not write & 45 & 58,4 \\
\hline Total & 77 & 100 \\
\hline
\end{tabular}


From Table 1 it appears that 77 trainees, from a population of 101 trainees employed in a mid-sized, international accounting firm, participated in the study. Their ages ranged from 22 to 26 years. The sample represented an approximate equal distribution of males and females, although most participants' ethnicity was White. Of the 77 participants, most were post graduates and in their second year of traineeship. Most trainees that qualified to write the QE Part 1 and those that qualified to write Part 2 passed as first time writers. Due to the logistical and cost implications of involving all trainees at all the offices of the firm, the sample size was smaller than was anticipated prior to commencing with the study. This could lead to the researchers not being able to infer that the population in question has the observed properties from the sample.

\section{Measuring instruments}

In this study, a test battery consisting of the normative version of the OPQ 32 (Occupational Personality Questionnaire), the Verbal Evaluation and Interpreting Data Questionnaires, as well as a performance measurement scale, as developed by the researchers, were used. The trainees' academic achievements for the subjects of Accounting and Auditing over a four year period as well as their pass rate relating to the QE were also included as predictor variables. The instruments are listed in Table 2.

TABLE 2

DESCRIPTIVE STATISTICS AND INTERNAL CONSISTENCY RELIABILITIES OF THE PREDICTOR AND CRITERION VARIABLES $(\mathbf{N}=\mathbf{7 7})$

\begin{tabular}{|c|c|c|c|c|c|c|}
\hline Variables & M & SD 1 & Maximum & Minimum & $\begin{array}{l}\text { Number } \\
\text { of Items }\end{array}$ & $\begin{array}{c}\text { Cronbach } \\
\text { Alpha }\end{array}$ \\
\hline \multicolumn{7}{|l|}{ Predictor variables } \\
\hline OPQ Data rational & 24,62 & 3,41 & 31 & 14 & & \\
\hline OPQ Evaluative & 24,79 & 3,96 & 35 & 15 & & \\
\hline OPQ Adaptable & 21,13 & 4,82 & 30 & 8 & & \\
\hline OPQ Detail conscious & 26,19 & 4,88 & 36 & 12 & & \\
\hline OPQ Rule following & 22,06 & 4,44 & 32 & 10 & & \\
\hline Verbal evaluation & 45,00 & 6,15 & 56 & 29 & & \\
\hline Interpreting data & 26,87 & 5,27 & 38 & 13 & & \\
\hline \multicolumn{7}{|l|}{ Academic achievement } \\
\hline Ave mark in $1^{\text {st }}$ year & 67,14 & 10,28 & $8 \quad 90,4$ & 48,2 & & \\
\hline Ave mark in $2^{\text {nd }}$ year & 63,54 & 8,97 & 45,2 & 85,4 & & \\
\hline Ave mark in $3^{\text {rd }}$ year & 60,50 & 8,34 & 81,8 & 43,7 & & \\
\hline Ave mark in $4^{\text {th }}$ year & 54,61 & 8,03 & 83,2 & 35,8 & & \\
\hline $\begin{array}{l}\text { Accounting results } \\
1^{\text {st }} \text { year }\end{array}$ & 66,69 & 11,23 & 393,0 & 50,0 & & \\
\hline $\begin{array}{l}\text { Accounting results } \\
2^{\text {nd }} \text { year }\end{array}$ & 63,18 & 10,06 & 691,0 & 50,0 & & \\
\hline $\begin{array}{l}\text { Accounting results } \\
3^{\text {rd }} \text { year }\end{array}$ & 59,92 & 8,88 & 87,0 & 45,0 & & \\
\hline $\begin{array}{l}\text { Accounting results } \\
4^{\text {th }} \text { year }\end{array}$ & 54,68 & 7,98 & 78,0 & 34,0 & & \\
\hline \multicolumn{7}{|l|}{ Criterion variables } \\
\hline \multicolumn{7}{|l|}{ Technical Competencies } \\
\hline Planning the audit & 4,07 & 0,95 & 5,73 & 2,18 & 11 & 0,96 \\
\hline Working papers & 4,22 & 0,99 & 6,00 & 2,07 & 15 & 0,97 \\
\hline Financial statements & 4,09 & 1,17 & 6,00 & 1,50 & 4 & 0,93 \\
\hline Completion & 4,13 & 1,11 & 6,00 & 1,83 & 6 & 0,96 \\
\hline \multicolumn{7}{|c|}{ Behavioural Competencies } \\
\hline Professional behaviour & 4,38 & 1,09 & 6,00 & 2,00 & 4 & 0,93 \\
\hline Communication & 4,82 & 0,91 & 6,00 & 2,67 & 3 & 0,97 \\
\hline Team player & 4,49 & 0,92 & 6,00 & 2,00 & 4 & 0,91 \\
\hline Initiative & 4,15 & 1,00 & 6,00 & 2,00 & 4 & 0,94 \\
\hline Managing the team & 4,25 & 0,85 & 6,00 & 2,43 & 7 & 0,91 \\
\hline
\end{tabular}

\section{Predictor Variables}

\section{- The OPQ32n}

The OPQ32n measures 32 personality and motivational characteristics relevant to the world of work. The 230 items contained in the questionnaire measure thirty-two factors of personality whereby individuals indicate the extent to which they agree or disagree with a series of statements. The items are endorsed on a five point scale, ranging from strongly disagree to strongly agree. The instrument is regarded as valid and reliable (Messick, 1988). The alpha coefficients of the OPQ32n scales range from 0,60 to 0,87 (SHL, 2004).

- The Verbal Evaluation and Interpreting Data Questionnaires These questionnaires form part of the Critical Reasoning Test Battery (CRTB) of SHL (SHL, 2004). They are designed to assess reasoning skills at graduate level. The coefficient alpha for the CRTB is reported to be 0,84 (SHL, 2004). The 30 items contained in the Verbal Evaluation Questionnaire measure the ability to understand and evaluate the logic of various arguments. A statement has to be evaluated as true or untrue based on information provided. The 30 items contained in the Interpreting Data Questionnaire measure the ability to make correct decisions or inferences from numerical data. Time limits of 30 minutes apply to both these questionnaires.

- Academic Achievement

The academic achievement of the subjects in Auditing and Accounting from their first year of study at university through to their fourth and final year at university was obtained from their academic records.

- Pass rate on the $\mathrm{QE}$ Part 1 and $\mathrm{QE}$ Part 2

The results of the participants' $\mathrm{QE}$ attempts were obtained from the $\mathrm{PAAB}$ and trainee records available at the firm.

\section{Criterion measure}

To obtain a performance criterion that might predict the success of trainees and against which the scores on the predictive measures could be correlated, a performance evaluation instrument was compiled by the first author in conjunction with a focus group of managers in the firm. The objective of the appraisal was to measure the performance of trainees during their traineeship year.

The performance assessment questionnaire comprises four dimensions consisting of a total of 36 items measuring the trainee's technical competence and five dimensions consisting of a total of 22 items assessing the trainee's behavioural competence. The items are endorsed on a six point scale ranging from one, representing poor performance that did not meet the rater's expectations, to six, for performance rated as exceptional. Items were regarded as not applicable, if they focused on behaviours not performed by the trainee. The intercorrelation matrix of the dimensions is given in Table 3 . It was predicted that trainees regarded as successful by the firm would score an average rating of 4.5 .

\section{Procedure}

The Work Profiling System (WPS) of SHL South Africa was used to produce a person specification that provides a description of traits that a trainee should possess in order to be regarded as successful in the firm's environment. The WPS was compiled in conjunction with a focus group of management in the firm. Deducted from the WPS profile and based on previous research, five traits measured by the OPQ32n that could predict the success of trainees were identified, namely Data Rational (High scorers like working with numbers, enjoys analysing statistical information and base decisions on facts and figures), Evaluative (High scorers critically evaluate information and like to look at the potential problems of an approach), Detail Conscious (High scorers focus on detail and like to be methodical, organised and systematic), Adaptable (High scorers vary their approach according to the situation 
and people involved) and Rule Following (High scorers prefer clear guidelines, follow rules and regulations and regard these as a way to maintain standards).

The same administrator administered the test battery, consisting of the OPQ32n as well as the Verbal Evaluation and Interpreting Data Questionnaires, to the 77 trainees. Forty trainees were assessed during the first session, and 37 trainees during the second session. Participants were informed that the purpose of the research was to determine whether there is a correlation between their personality profiles, their performance evaluation scores and their academic results. Participants were assured that their results would be regarded as confidential by the researcher. Seventy-seven fully completed and usable sets were received.

The Performance Evaluation Questionnaire was distributed to senior members of the audit team. Due to the nature of the audit environment, trainees were not all rated by the same raters. Raters all received performance evaluation sensitisation before they were requested to assess the trainees' performance. In an attempt to increase the objectivity and honesty of the ratings, raters were assured that the data would be kept confidential. The completed performance evaluations were collected from the raters by the first author.

\section{Statistical analysis}

The statistical analysis was conducted in two phases where the focus in phase one was on establishing the reliabilities of the scales or variables to be used in the second stage of the data analyses.

The second phase of the data analysis focused on the inferential statistical analysis where the work performance of the trainee accountants were predicted.

The statistical analyses were conducted by the Statistical Consultation Service of the University of Johannesburg.

\section{RESULTS}

First phase of the data analyses

The 77 returned performance evaluations were statistically analysed. Since some items were regarded as not applicable for measuring the technical or behavioural competencies, the average performance per candidate was determined only in respect of those items applicable to the specific candidate. Based on the median appraisal scores of the candidates, the candidates were divided into two more or less equal sized groups, namely successful and not successful. The median value equals 4,5 . This yielded 35 successful trainees and 42 trainees that were regarded as not successful.

To determine the reliability of the criterion measure, factor analyses on two levels and an iterative item analysis were conducted. To establish whether the item intercorrelation matrix (refer to Table 3) was suitable for factor analysis, the KaiserMeyer-Olkin (KMO) measure of sampling adequacy and Bartlett's Test of Sphericity were performed on the matrix. These values (not reported here owing to limited space) were on acceptable levels.

Eigenvalues were calculated for the item inter-correlation matrix in order to postulate the number of factors (Eigenvalues larger than unity) to be extracted and subsequently subscores were calculated for each factor. A second level factor analysis was then performed where the subscores were intercorrelated. Again the KMO measure of sampling adequacy $(0,910)$ and Bartlett's Test of Sphericity $\left(\mathrm{X}^{2}=493,833 ; \mathrm{df}=36 ; \mathrm{p}=0,000\right)$ were performed on the subscore intercorrelation matrix and these values were deemed acceptable. Eigenvalues were calculated for the subscore matrix (refer to Table 4) and the single factor postulated (Eigenvalue larger than unity) explained about $70 \%$ variance in the given factor space. An iterative item analysis yielded an internal consistency reliability (Cronbach alpha) of 0,95 . Since Anastasi (1997) concluded that desirable reliability coefficients for criterion measures fall in the $0,80 \mathrm{~s}$ or $0,90 \mathrm{~s}$, this scale is reliable for use in the research. The factor loadings of the different factors on the single extracted factor are displayed in Table 5 .

To ascertain to what extent the two groups differ in terms of their average academic performance, cross-tabulations together with Chi-Square tests were performed in respect of the successful and unsuccessful candidates and whether the candidates passed each year of study (in terms of the subjects of Financial Accounting and Auditing) as first time writers or whether they had to the repeat the respective subject. In terms of whether or not Auditing 4 was repeated a significant difference was obtained (Pearson Chi-Square [with continuous correction $]=3,443, \mathrm{df}=1, \mathrm{p}$-value $=0,064)$ at the $10 \%$ level (refer to Table 6).

TABLE 3

INTERCORRELATIONS BETWEEN THE DIMENSIONS OF THE CRITERION VARIABLES ( $\mathbf{N}=\mathbf{5 4}$ )

\begin{tabular}{|c|c|c|c|c|c|c|c|c|c|c|c|}
\hline & & Planning & $\begin{array}{c}\text { Working } \\
\text { papers }\end{array}$ & $\begin{array}{c}\text { Financial } \\
\text { statements }\end{array}$ & Completion & $\begin{array}{c}\text { Professional } \\
\text { behaviour }\end{array}$ & $\begin{array}{l}\text { Communi- } \\
\text { cation }\end{array}$ & $\begin{array}{l}\text { Team } \\
\text { player }\end{array}$ & $\begin{array}{l}\text { Initiative } \\
\text { the team }\end{array}$ & Managing & $\begin{array}{l}\text { Overall mean } \\
\text { performance }\end{array}$ \\
\hline Planning & Pearson correlation & 1,000 & & & & & & & & & \\
\hline Working papers & Pearson correlation & 0,958 & 1,000 & & & & & & & & \\
\hline Financial statements & Pearson correlation & 0,854 & 0,885 & 1,000 & & & & & & & \\
\hline Completion & Pearson correlation & 0,898 & 0,906 & 0,851 & 1,000 & & & & & & \\
\hline Professional behaviour & Pearson correlation & 0,464 & 0,495 & 0,484 & 0,496 & 1,000 & & & & & \\
\hline Communication & Pearson correlation & 0,535 & 0,572 & 0,522 & 0,487 & 0,409 & 1,000 & & & & \\
\hline Team player & Pearson correlation & 0,633 & 0,653 & 0,636 & 0,558 & 0,447 & 0,758 & 1,000 & & & \\
\hline Initiative & Pearson correlation & 0,768 & 0,811 & 0,824 & 0,724 & 0,467 & 0,571 & 0,691 & 1,000 & & \\
\hline Managingthe team & Pearson correlation & 0,734 & 0,723 & 0,680 & 0,624 & 0,359 & 0,517 & 0,694 & 0,668 & 1,000 & \\
\hline $\begin{array}{l}\text { Overall mean } \\
\text { performance }\end{array}$ & Pearson correlation & 0,923 & 0,945 & 0,913 & 0,888 & 0,620 & 0,699 & 0,796 & 0,878 & 0,794 & 1,000 \\
\hline
\end{tabular}

All coefficients were significant at the 0,01 level 
TABLE 4

EIGENVALUES OF THE UNREDUCED SUBSCORE INTERCORRELATION MATRIX ON THE CRITERION MEASURE

\begin{tabular}{lccc}
\hline Factor & \multicolumn{3}{c}{ Total Variance Explained Initial Eigenvalues } \\
\% of Variance & Cumulative \% \\
\hline 1 & Total & 69,864 & 69,864 \\
2 & 6,288 & 9,494 & 79,358 \\
3 & 0,854 & 7,846 & 87,204 \\
4 & 0,706 & 4,430 & 91,634 \\
5 & 0,399 & 3,359 & 94,994 \\
6 & 0,302 & 2,021 & 97,015 \\
7 & 0,182 & 1,517 & 98,532 \\
8 & 0,137 & 1,056 & 99,588 \\
9 & 0,095 & 0,412 & 100,000 \\
\hline
\end{tabular}

Extraction Method: Principal Axis Factoring.

TABLE 5

FACTOR MATRIX OF CRITERION VARIABLES

\begin{tabular}{lcc}
\hline & Factor Matrix (a) & \\
& Factor 1 & Communalities \\
\hline Working papers (Logic) & 0,959 & 0,867 \\
Planning & 0,931 & 0,920 \\
Technical statements (Financial) & 0,908 & 0,824 \\
Completion & 0,876 & 0,767 \\
Initiative & 0,862 & 0,287 \\
Management of resources & 0,771 & 0,424 \\
Team player & 0,764 & 0,584 \\
Manner & 0,651 & 0,743 \\
Professional Behaviour & 0,536 & 0,594 \\
Extraction Method: Principal Axis Factoring. & & \\
\hline
\end{tabular}

a) 1 factor extracted. 4 iterations required.

TABLE 6

Cross-tabulation of academic pass rate ON AUDITING 4 AND SUCCESS

\begin{tabular}{|c|c|c|c|c|c|}
\hline & Frequen & & Successful & Not & Total \\
\hline \multirow{4}{*}{$\begin{array}{l}\text { \# Repeating } \\
\text { Auditing } 4\end{array}$} & 1 time & Observed & 29 & 25 & 54 \\
\hline & & Expected & 25 & 29 & \\
\hline & 2 times & Observed & 37 & 11 & 14 \\
\hline & & Expected & 7 & 7 & \\
\hline Total & & Count & 32 & 36 & 68 \\
\hline
\end{tabular}

Chi-Square Tests

Value df Asymp. Exact Sig. Exact Sig Sig. (2-sided) (2-sided) (1-sided)

\begin{tabular}{lccc}
\hline Pearson Chi-Square & 4,649 (b) & 1 & 0,031 \\
Continuity Correction (a) & 3,443 & 1 & 0,064 \\
Likelihood Ratio & 4,921 & 1 & 0,027
\end{tabular}

Fisher's Exact Test

Linear-by-Linear Association $4,580 \quad 1 \quad 0,032$

No of Valid Cases

68

a. Computed only for a $2 \times 2$ table.

b. 0 cells $(0 \%)$ have expected count less than 5 . The minimum expected count is 6,59 .
Cross tabulations together with Chi-Square tests were performed between the groups that were regarded as successful or not successful and whether they passed the QE part 1 and Part 2 as first time or repeat writers. The cross tabulations indicated that $74,3 \%$ of trainees that passed the QE part 1 as first time writers, were classified as successful (refer to Table 7). Of those trainees that passed the QE part 2 as first time writers, $51,4 \%$ were classified as successful (refer to Table 8). In each case, statistically significant differences were obtained between the successful and the unsuccessful group.

TABle 7

Cross-tabulations of QE Part 1 and success

\begin{tabular}{lllccc}
\hline & & Frequency Successful & $\begin{array}{c}\text { Not } \\
\text { successful }\end{array}$ & Total \\
\hline QE part 1 & Passed & Observed & 26 & 13 & 39 \\
& 1 1st time & Expected & 18 & 21 & \\
& Passed & Observed & 2 & 9 & 11 \\
& when & Expected & 5 & 6 & \\
& repeated & & & & \\
& Did not & Observed & 7 & 20 & 27 \\
Trite & Expected & 12 & 15 & \\
& Count & & 35 & 42 & 77 \\
\hline
\end{tabular}

Chi-Square Tests

\begin{tabular}{|c|c|c|c|}
\hline & Value & df & Asymp. Sig. (2-sided) \\
\hline Pearson Chi-Square & $14,531^{\text {(a) }}$ & 2 & 0,001 \\
\hline \multicolumn{4}{|l|}{ Continuity Correction } \\
\hline Likelihood Ratio & 15,125 & 2 & 0,001 \\
\hline Linear-by-Linear Association & 11,390 & 1 & 0,001 \\
\hline $\mathrm{N}$ of Valid Cases & 77 & & \\
\hline
\end{tabular}

a. 0 cells ( $0 \%$ ) have expected count less than 5 . The minimum expected count is 5,00.

Symmetric Measures

a. Not assuming the null hypothesis.

b. Using the asymptotic standard error assuming the null hypothesis.

TABLE 8

Cross-tabulations of QE Part 2 and success

\begin{tabular}{lllccc}
\hline & & Frequency Successful & $\begin{array}{c}\text { Not } \\
\text { successful }\end{array}$ & Total \\
\hline QE part 2 & Passed & Observed & $\mathbf{1 8}$ & 9 & 27 \\
& 1st time & Expected & 12 & 15 & \\
& Passed & Observed & $\mathbf{0}$ & $\mathbf{5}$ & 5 \\
& when & Expected & 2 & 3 & \\
repeated & & & & \\
& Did not & Observed & $\mathbf{1 7}$ & $\mathbf{2 8}$ & 45 \\
Total & Exite & Expected & 20 & 25 & \\
\hline
\end{tabular}

Chi-Square Tests

\begin{tabular}{lccc}
\hline & Value & df & Asymp. Sig. (2-sided) \\
\hline Pearson Chi-Square & $10,136^{(a)}$ & 2 & 0,006 \\
Continuity Correction & & & \\
Likelihood Ratio & 12,069 & 2 & 0,002 \\
Linear-by-Linear Association & 4,951 & 1 & 0,026 \\
N of Valid Cases & 77 & & \\
\hline
\end{tabular}

a. 2 cells $(33,3 \%)$ have expected count less than 5 . The minimum expected count is 2,27 . 
Symmetric Measures

\begin{tabular}{|c|c|c|c|c|c|}
\hline & & Value & $\begin{array}{l}\text { Asymp. Std. } \\
\text { Error }^{(a)}\end{array}$ & $\underset{T^{(b)}}{\text { Approx. }}$ & $\begin{array}{l}\text { Approx. } \\
\text { Sig. }\end{array}$ \\
\hline \multirow[t]{2}{*}{ Nominal by Nominal } & Phi & 0,363 & & & 0,006 \\
\hline & Cramer's V & 0,363 & & & 0,006 \\
\hline $\mathrm{N}$ of Valid Cases & 77 & & & & \\
\hline
\end{tabular}

a. Not assuming the null hypothesis.

b. Using the asymptotic standard error assuming the null hypothesis.

Due to the small sample size, no factor analysis was performed on the OPQ32n. (These scales should thus be interpreted with caution). The internal consistency of each OPQ32n dimension for this sample was determined by calculating Cronbach's coefficient alpha (provided by SHL). All these obtained coefficients were at acceptable levels (refer to Table 9) and could therefore be included in the equation.

TABle 9

OPQ32N MEANS, STANDARD DEVIATIONS AND ALPHA COEFFICIENTS $(\mathbf{N}=\mathbf{7 7})$

\begin{tabular}{|c|c|c|c|}
\hline Scale number and name & Mean score & $\begin{array}{r}\text { Standard } \\
\text { deviation }\end{array}$ & $\begin{array}{c}\text { Coefficient } \\
\text { alpha }\end{array}$ \\
\hline R1 - Persuasive & 21,80 & 5,37 & 0,91 \\
\hline R2 - Controlling & 23,13 & 3,92 & 0,83 \\
\hline R3 - Outspoken & 21,57 & 4,75 & 0,79 \\
\hline R4 - Independent minded & 21,00 & 4,22 & 0,70 \\
\hline R5 - Outgoing & 22,13 & 5,67 & 0,91 \\
\hline R6 - Affiliative & 25,04 & 5,30 & 0,86 \\
\hline R7 - Socially confident & 22,27 & 4,73 & 0,86 \\
\hline R8 - Modest & 19,44 & 4,97 & 0,89 \\
\hline R9 - Democratic & 25,20 & 4,26 & 0,77 \\
\hline R10 - Caring & 26,21 & 5,15 & 0,85 \\
\hline $\mathrm{T} 1$ - Data rational & 24,51 & 3,37 & 0,71 \\
\hline $\mathrm{T} 2$ - Evaluative & 24,83 & 3,99 & 0,77 \\
\hline T3 - Behavioural & 25,68 & 4,89 & 0,85 \\
\hline T4 - Conventional & 19,45 & 5,45 & 0,86 \\
\hline T5 - Conceptual & 23,39 & 4,27 & 0,72 \\
\hline T6 - Innovative & 22,44 & 4,80 & 0,87 \\
\hline T7 - Variety seeking & 24,11 & 4,17 & 0,66 \\
\hline T8 - Adaptable & 21,24 & 4,74 & 0,80 \\
\hline T9 - Forward thinking & 24,41 & 4,02 & 0,83 \\
\hline T10 - Detail conscious & 26,16 & 4,89 & 0,79 \\
\hline T11 - Conscientious & 25,92 & 3,66 & 0,83 \\
\hline T12 - Rule following & 22,08 & 4,50 & 0,79 \\
\hline F1 - Relaxed & 21,07 & 5,56 & 0,92 \\
\hline F2 - Worrying & 21,00 & 5,38 & 0,92 \\
\hline F3 - Tough minded & 19,15 & 4,76 & 0,85 \\
\hline F4 - Optimistic & 27,25 & 4,97 & 0,86 \\
\hline F5 - Trusting & 19,47 & 5,38 & 0,85 \\
\hline F6 - Emotional control & 20,48 & 4,86 & 0,88 \\
\hline F7 - Vigorous & 26,97 & 3,99 & 0,76 \\
\hline F8 - Competitive & 17,37 & 5,18 & 0,88 \\
\hline F9 - Achieving & 28,67 & 3,57 & 0,74 \\
\hline F10 - Decisive & 17,80 & 3,62 & 0,69 \\
\hline SD - Social Desirability & 18,72 & 4,87 & 0,77 \\
\hline
\end{tabular}

Second phase of the data analyses

To predict work performance, based on the predictor variables with established reliabilities, a stepwise regression was performed. (Split sample confirmation procedures could not be performed due to the small sample size). The variables Data Rational, Evaluative, Rule Following, Adaptable, Detail Conscious, Verbal Evaluation and Interpreting data were entered into the equation and only one variable was extracted, namely Verbal Evaluation. This predictor variable alone, explained $21 \%$ of the variance. Scores on the Verbal Evaluation Questionnaire can thus be regarded as a meaningful predictor of trainee accountants' work performance (refer to Table 10).

TABLE 10

STEPWISE REGRESSION FOR PREDICTING WORK PERFORMANCE

\begin{tabular}{lcccc}
\hline \multicolumn{5}{c}{ Model Summary } \\
\hline Model & $\mathbf{R}$ & R Square & $\begin{array}{l}\text { Adjusted } \\
\text { R Square }\end{array}$ & $\begin{array}{c}\text { Std. Error of } \\
\text { the Estimate }\end{array}$ \\
\hline 1 & $0,457^{\text {(a) }}$ & 0,208 & 0,198 & 0,7731 \\
\hline a Predictors: (Constant), Verbal evaluation & &
\end{tabular}

ANOVA(b)

\begin{tabular}{llccccc}
\hline Model & Sum of Squares & df & Mean Square & F & Sig. \\
\hline 1 & Regression & 11,803 & 1 & 11,803 & 19,747 & $0,000^{(a)}$ \\
& Residual & 44,829 & 75 & 0,598 & & \\
Total & 56,632 & 76 & & & \\
\hline
\end{tabular}

a Predictors: (Constant), Verbal evaluation

b Dependent Variable: Overall mean - Performance

\begin{tabular}{|c|c|c|c|c|c|c|c|c|}
\hline \multicolumn{9}{|c|}{ Coefficients(a) } \\
\hline \multirow[t]{2}{*}{ Model } & \multicolumn{2}{|c|}{$\begin{array}{l}\text { Unstandardised } \\
\text { Coefficients }\end{array}$} & \multicolumn{2}{|c|}{$\begin{array}{l}\text { Standardised } \\
\text { Coefficients }\end{array}$} & \multirow[b]{2}{*}{ Sig. } & \multicolumn{3}{|c|}{ Correlations } \\
\hline & B & Std. Error & Beta & $t$ & & $\begin{array}{l}\text { Zero- } \\
\text { order }\end{array}$ & Partial & Part \\
\hline 1 (Constant) & ) 1,438 & 0,655 & & 2,195 & 0,031 & & & \\
\hline $\begin{array}{l}\text { Verbal } \\
\text { evaluation }\end{array}$ & $6,411 \mathrm{E}-02$ & 0,014 & 0,457 & 4,444 & 0,000 & 0,457 & 0,457 & 0,457 \\
\hline
\end{tabular}

a Dependent Variable: Overall mean - Performance

When a log linear regression was performed on the categorical criterion variable (successful candidates and non-successful candidates), once again only the Verbal Evaluation variable was extracted as a significant predictor. In this instance $61 \%$ of cases were correctly predicted as successful or not by using the Verbal Evaluation scores as predictor variable (refer to Table 11).

TABLE 11

LOGISTICAL REGRESSION - CLASSIFICATION TABLE

\begin{tabular}{llccc}
\hline & & \multicolumn{3}{c}{ Predicted } \\
Observed & & $\begin{array}{c}\text { Success } \\
\text { Successful }\end{array}$ & $\begin{array}{c}<>4.5 \\
\text { Not } \\
\text { Successful }\end{array}$ & $\begin{array}{c}\text { Percentage } \\
\text { correct }\end{array}$ \\
\hline Step 1 Success $<>4.5$ & Successful & 18 & 14 & 56,3 \\
& Not successful & 12 & 22 & 64,7 \\
\multicolumn{1}{c|}{ Overall percentage } & & & & 60,6
\end{tabular}

a. The cut value is 0,500

Variables in the Equation

\begin{tabular}{ccccccc}
\hline & B & S.E. & Wald & df & Sig. & $\operatorname{Exp(B)}$ \\
\hline Step 1 Verbal Evaluation & $-0,097$ & 0,046 & 4,481 & 1 & 0,34 & 0,907 \\
& 4,506 & 2,122 & 4,510 & 1 & 0,34 & 90,549 \\
\hline
\end{tabular}

Variable(s) entered on Step 1: Verbal Evaluation 


\section{DISCUSSION}

The primary objective of this study was to examine whether a psychological, academic, skills and abilities profile, as predetermined by organisational requirements, significantly predicts the actual rated performance of a trainee. The results of the first phase analyses indicate that the reliabilities of the criterion and predictor variables were at an acceptable level and could therefore be used in the analyses that followed. In order to determine which types of final examinations could be used as predictors, cross tabulations and Chi-square analyses were conducted and significant differences were found between successful and unsuccessful students with regard to the Qualifying Examinations 1 and 2.

To determine whether trainees could be regarded as successful or not, the log linear regression method indicated that, by chance, $51 \%$ of cases could be predicted as successful or not. Once the predictor variables were entered into the equation, it resulted in $61 \%$ of cases being correctly predicted by the variable Verbal Evaluation. When the process was repeated using the Stepwise regression method, it was reiterated that only Verbal Evaluation could be regarded as the best predictor of performance. Besides significant differences between successful and unsuccessful candidates in respect of the subject Auditing 4 and QE (part 1 and 2) no further significant evidence was found of an association between the predictor variables measured and trainee performance. Hereby the research question of the study was answered. Therefore, a conclusion that most of the variables studied herein have a causal effect on trainee accountants' work performance would be unwarranted.

Results reported present evidence that academic performance as well as the ability to reason verbally should be considered during selection and recruitment of trainees. This supports findings by previous researchers. The value of trainees that pass their QE was emphasised by Harvey-Cook (2000) and this is consistent with the findings presented in this research study.

This study confirmed previous research that factors such as academic achievement, numerical ability and competence in the use of language (verbal ability) influence the performance of a trainee on the job. No links could be drawn between the findings of previous research on the studied personality traits, such as flexibility, innovation, integrity and interpersonal skills, since only Verbal Evaluation could be regarded as a significant indicator of success in this study.

A possible reason for these findings could be that the focus group that predicted the variables that should be the best indicators of trainee success, did not realise that these might not be the most significant predictors of success. The focus group should revisit and scrutinise the reasoning behind their prediction. Earlier research indicated the importance of factors such as innovation, integrity, self-confidence and perseverance. Perhaps these traits should be regarded more highly by the focus group. It is apparent that personality measures can be beneficial for the prediction of success of trainees, but their use in selection requires a careful match with the traits that really are the best indicators.

Certain implications follow from the foregoing conclusions. During this study emphasis was placed on the benefit of making use of scientific psychological measurements in selecting accountancy graduates that would fit into the firm and the benefit thereof to both parties. The questionnaire compiled to evaluate the performance of the sample on the job has a high reliability (alpha $=0,95$ ) and could confidently be used in this firm as a fair and reliable measure for assessing work performance. Also, the Verbal Evaluation Questionnaire could be used during selection and recruitment, serving as a better indicator of future success than just relying on chance.
The study has certain limitations. Due to underlying differences between accounting firms and relying on a sample of trainees from only one medium-sized, international firm in South Africa, it is not possible to generalise the findings across the profession unless they correlate with previous studies. It could however, prove valuable for similar sized firms with a similar culture. Broadening the sample to include trainees of other accounting firms as well should increase the reliability of conclusions about the associations of the mentioned personality and academic attributes with the success of trainees in the work environment.

Suggestions for future research include the influence that their year of traineeship could have on the way that they are performing on the audit. During the first year of traineeship the work is still perceived as interesting and challenging and might drive trainees to better performance. Should the trainees not have a high tolerance for routine, their performance could decrease by their third year of traineeship and the matching of the personality profile might not be a good predictor. Also, the importance of socialisation into the firm's environment could, according to Fogarty (2000) have a great impact on the competence and performance that a trainee exhibits. The process of socialisation was not addressed in this study.

The present research does not improve on existing research that has already evaluated the importance of personality, behavioural, intellectual and technical ability as success factors of trainees but reiterates the importance of effective selection and recruitment of trainees for the future of the accounting profession in South Africa. A more objective selection tool that will indicate return on investment in the longer term should be used in order to justify the amount of resources, monetary and non-monetary, that is allocated to the selection and recruitment process of accountancy graduates in South Africa. This study emphasised that luck alone should not be relied upon in the selection of trainees. Insufficient assessment of the accounting graduate may lead to disappointing results for the trainee and the accounting firm

\section{ACKNOWLEDGEMENT}

The authors wish to thank Professor Delene Visser who was involved in the initial design and analyses phases of the study.

\section{REFERENCES}

Anastasi, A. (1997). Psychological testing (9th ed.). Upper Saddle River, NJ: Prentice Hall.

Anderson-Gough, F., Grey, C. \& Robson, K. (1998). Making up accountants: The organizational and professional socialization of trainee chartered accountants. Vermont, USA: Ashgate.

Barber, A.E. (1998). Recruiting employees: Individual and organizational perspectives. Thousand Oaks, California: Sage.

Boolsen, M. \& Theron, C.C. (1996). Kennisbasisse, gebruikspatrone en gebruikshindernisse ten opsigte van die riglyne vir die ontwikkeling en validering van personeelkeuringsprosedures. [Knowledge bases, user patterns and user obstacles in terms of the guidelines for the developments and validation of personnel selection procedures]. Tydskrif vir Bedryfsielkunde, 22 (2), 7-14.

Boress, A.S. (1999). Stopping brain drain. Journal of Accountancy, September, 10-17.

Caldwell, D.F., Chatman, J.A. \& O'Reilly, C.A. (1990). Building organizational commitment: A multifirm study. Journal of Occupational Psychology, 63, 245-261.

Caldwell, D.F. \& O'Reilly, C.A. (1990). Measuring person-job fit with a profile-comparison process. Journal of Applied Psychology, 75 (6), 648-657.

Chatman, J.A. (1991). Matching people and organizations: Selection and socialization in public accounting firms. Administrative Science Quarterly, 36 (3), 459-480. 
Collins, S.H. (1987). Recruiting and retaining the best and the brightest in today's economic market. Journal of Accountancy, February, 52-58.

Cummings, B., Bennett, R.E., Normand, C.J. (2001). Meeting the challenge: The auniversity accounting program corporate America needs. Management Accounting Quarterly, Winter, 31-42.

Day, D.V. \& Silverman, S.B. (1989). Personality and job performance: Evidence of incremental validity. Personnel Psychology, 42, 25-36.

Dean, R.A., Ferris, K.R. \& Konstans, C. (1988). Occupational reality shock and organizational commitment: evidence from the accounting profession. Accounting, Organizations and Society, 13 (3), 235-251.

Dunn, W.M. \& Hall, T.W. (1984). An empirical analysis of the relationships between CPA examination candidate attributes and candidate performance. The Accounting Review, LIX (4), 674-689.

Elkins, T.J. \& Phillips, J.S. (2000). Job context, selection decision outcome and the perceived fairness of selection tests: biodata as an illustrative case. Journal of Applied Psychology, 85 (3), 479-484.

England, J. (1991). Personality assessment: a review with special reference to the South African situation. Pretoria: Human Sciences Research Council.

Fogarty, T.J. (2000). Socialization and organizational outcomes in large public accounting firms. Journal of Managerial Issues, Spring, 13-21.

Gaffney, M.A., McEwen, R.A. \& Welsch, M.J. (1990). Advice to firms: Gender differences in expectations of success impacts recruiting. The CPA Journal, LX (9), 86-89.

Garavan, T.N. \& Morley, M. (1997). The socialization of highpotential graduates into the organization: initial expectations, experiences and outcomes. Journal of Management Psychology, 12 (1), 118-138.

Grey, C. (1998). On being a professional in a "Big Six" firm. Accounting, Organizations and Society, 23 (5), 569-573.

Harvey-Cook, J.E. (2000). Biodata in professional entry-level selection: Statistical scoring of common format applications. Journal of Occupational and Organizational Psychology, 73 (1), 103-119.

Harvey-Cook, J.E. \& Taffler, R.J. (1987). Graduate recruitment procedures in the UK accountancy profession: A preliminary study. Accounting and Business Research, 22 (2), 99-108.

Harvey-Cook, J.E. \& Taffler, R.J. (1997). Towards a recruitment revolution. Accountancy - International Edition, February, 40-41.

Herriot, P. (1984). Down from the ivory tower. London: Input Typesetting.

Holland, J.L. (1973). Making vocational choices. Englewood Cliffs, NJ: Prentice-Hall.

Holub, S.F. (1998). Staffing the accounting firm in the new millenium. The Tax Adviser, 29 (9), 632-635.
Hulme, Z. (1998). Werwing en potensiaalidentifisering van leerlinggeoktrooieerde rekenmeesters. [Recruitment and identification of potential of trainee accountants]. Ongepubliseerde magisterverhandeling. Universiteit van Suid Afrika, Pretoria.

Jeffords, R., Scheidt, M. \& Thibadoux, G.M. (2000). Securing the future. Journal of Accountancy, February, 20-27.

Jones, S. (1991). A new approach to psychometric testing. Management Accounting, April, 46-48.

Karys, A. (1998). The best and brightest: Recruiting and retaining CPA's. Outlook, 65 (4), 18-24.

Kirsch, R.J. \& Leathers, P.E. (1993). Student versus recruiter perceptions of the importance of staff auditor performance variables. Accounting Horizons, 7 (4), 58-68.

Kristhof, A.L. (1996). Person-organization fit: An integrative review of its conceptualizations, measurement and implications. Personnel Psychology, 49, 1-49.

Larkin, J.M. (1990). Advice to recruiters and students: Making office visits effective. The CPA Journal, LX (9), 84-85.

Le Roux, H., Schepers, J.M. \& Lessing, B.C. (1997). The relationship between career maturity, career expectations and perceptions of job and organisational knowledge of engineering bursars. Journal of Industrial Psychology, 23 (2), 31-38.

Messick, S. (1988). Validity. In R.L. Linn (Ed.), Educational measurement (3rd ed.), (13-104). New York: American Council on Education and Macmillan Publishing.

Nell, T.L., Kamfer, L. \& Van der Merwe, R.P. (1996). Die persoonlikheidsprofiel van suksesvolle bewakingsdienspersoneel. [The personality profile of successful corrective service personnel]. Tydskrif vir Bedryfsielkunde, 22 (3), 7-12.

PAAB (Public Accountants' and Auditors' Board) (1998). Guidelines for Chartered Accountants and Auditors. Johannesburg: The Natal Witness.

Rynes, S. \& Gerhart, B. (1990). Interviewer assessments of applicant fit: An exploratory investigation. Personnel Psychology, 43, 13-34.

SAICA (The South African Institute of Chartered Accountants) (2004). Training Manual. Johannesburg: The Natal Witness.

Seeker, K.R. \& Wilson, J.B. (1998). Planning successful employee performance. London: Kogan Page Limited.

SHL. (2004). The Occupational Personality Questionnaire in South Africa: Psychometric Research Perspectives. Pretoria: SHL Group plc.

Simon, J. \& Kedslie, M. (1997). What are recruitment selectors looking for? Management Accounting (British), 75 (7), 58-61.

Thomas, P.B. \& Thomas, R.E. (1989). Nontraditional scheduling: A vehicle for attracting and retaining "the brightest and the best". The CPA Journal, 59 (11), 74-79.

Van der Walt, H.S. \& Esterhuyse, K.G.F. (1987). Development of a programme for evaluating candidates for training as chartered accountants. Pretoria: Human Sciences Research Council. Watson, M.B. \& Stead, G.B. (1997). Are career mature students more committed to the career choice process? Journal of Industrial Psychology, 23 (3), 20-21. 